\title{
Herpetofauna of San José del Guaviare, Guaviare, Colombia
}

\section{Herpetofauna de San José del Guaviare, Guaviare, Colombia}

\author{
Guido Fabian Medina-Rangel, Miguel Á. Méndez-Galeano and Martha Lucía Calderón-Espinosa
}

\begin{abstract}
We present the results of three years of sampling of amphibians and reptiles in different habitats in the municipality of San José del Guaviare, Guaviare, Colombia. We conducted four field excursions between 2012 and 2014 and found a total of 40 amphibian and 63 reptile species, representing a sampling coverage of $98 \%$ for amphibians and $93 \%$ for reptiles. Collection records and literature search increased our species list by 7 amphibians and 4 reptiles, for a total of 47 amphibians and 67 reptile species recorded for the region. Also, for the first time in Colombia, we documented the presence of the lizard Gymnophthalmus leucomystax, and confirmed the expansion of the distribution of the frog Boana maculateralis, and the snakes Atractus collaris, Atractus fuliginosus and Epictia amazonica in the department of Guaviare. Since most of the species found are from the central and western region of San José del Guaviare, sampling towards the eastern region, which has higher forest cover and less perturbed habitats, will undoubtedly increase the number of recorded species.
\end{abstract}

Keywords. Amphibians. Guiana Shield. Gymnophthalmus leucomystax. Representativeness. Reptiles. Species richness.

\section{Resumen}

Presentamos los resultados de tres años de muestreo de anfibios y reptiles en diferentes hábitats del municipio de San José del Guaviare, departamento del Guaviare. Hicimos cuatro salidas de campo entre 2012 y 2014. Encontramos un total de 40 especies de anfibios y 63 de reptiles, que representan una cobertura de muestreo del $98 \%$ para anfibios y 93 \% para reptiles. La revisión de los registros de las colecciones y la literatura nos permite añadir siete especies de anfibios y cuatro de reptiles a nuestra lista de especies, para un total de especies registradas en la región de 47 anfibios y 67 reptiles. Registramos por primera vez para Colombia la lagartija Gymnophthalmus leucomystax, y confirmamos la ampliación de la distribución en Colombia de la rana Boana maculateralis y de las serpientes Atractus collaris, Atractus fuliginosus y Epictia amazonica. La mayoría de los registros provienen de la región central y occidental de San José del Guaviare, por lo que el muestreo hacia la región oriental, donde la cobertura forestal es mayor y los hábitats menos perturbados, sin duda aumentarán el número conocido de especies.

Palabras clave. Anfibios. Escudo Guayanés. Gymnophthalmus leucomystax. Reptiles. Riqueza y representatividad. 


\section{Introduction}

The richness of amphibians and reptiles in Colombia represents about $11 \%$ (834) and $6 \%$ (606), respectively, of the global species richness in these groups (RuedaAlmonacid et al., 2004; Frost, 2019; Uetz et al., 2019). However, composition and richness of both groups in many areas, such as the Guiana Shield in the northern Amazonia region in Colombia, is poorly known.

There is a single published study of herpetofauna for the Guaviare department, and it is the result of the rapid biological inventories of the Field Museum published by Mueses-Cisneros \& Caicedo-Portilla (2018), who report 30 species of amphibians and 56 of reptiles from the rocky outcrops of the Lindosa region; however, these authors estimate 60 and 90 species of amphibians and reptiles, respectively, for the region due to the biogeographic influence of the Amazon, Orinoquia, Guiana Shield and Andean system regions. Notwithstanding the short time period of sampling, Mueses-Cisneros \& Caicedo-Portilla (2018) recorded two undescribed species, one amphibian of the genus Leptodactylus and one snake of the genus Dendrophidion, and expanded the distribution of two species of frogs: Allobates picachos and Osteocephalus deridens.
Here we include the results of three years of sampling in tropical wet forest, flooded forest, forest of rocky outcrops, savanna and open anthropic habitats in the municipality of San José del Guaviare, Guaviare, Colombia. Our aim is to present a preliminary species list of the amphibians and reptiles of the municipality based on fieldwork, records of herpetological collections and a literature review. We estimated the species richness, abundance and sampling representativeness of these group in this region.

\section{Materials and methods}

Study site. Fieldwork was conducted in different locations of the municipality of San José del Guaviare, Guaviare department (Figure 1; $2^{\circ} 30^{\prime}-2^{\circ} 33^{\prime} \mathrm{N}, 72^{\circ} 42^{\prime}-72^{\circ} 43^{\prime} \mathrm{W}$, datum Bogotá WGS 84, 180-230 m a. s. 1.). The sampling area is within the Guiana Shield region, in a transition zone between the Amazonian forests and the Orinoquia grassland vegetation, which includes paleozoic rocky outcrops, grasslands, wetlands, and native forests (Figure 2 A-D; Prance, 1996; Huber, 2006; Hammond, 2005; Kok et al., 2006; Cárdenas-López et al., 2008). The annual average monthly temperature is around $34^{\circ} \mathrm{C}$ and the average monthly rainfall is around $201 \mathrm{~mm}$ (dry month: January, and the most rainy month: July; Rangel-Ch. et al., 1997).

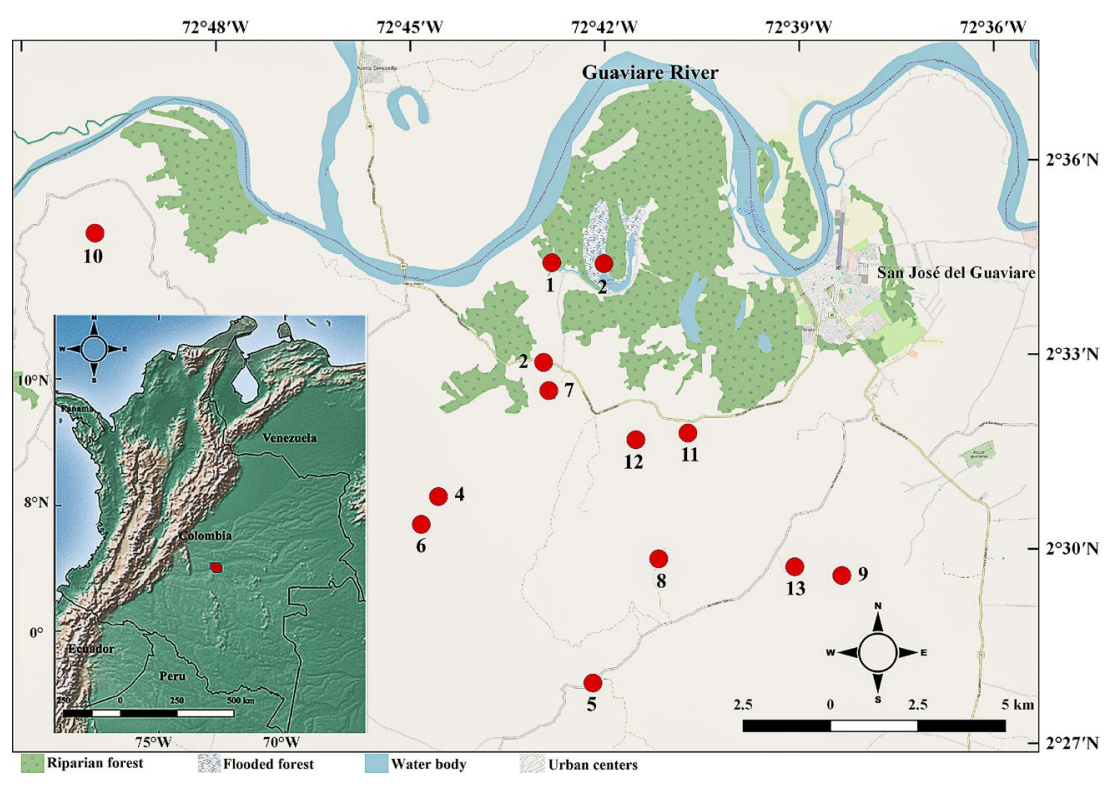

Figure 1. Distribution map for the herpetofauna sampling sites in San José del Guaviare, Guaviare, Colombia. The name of each numbered site is found in Table 1. 

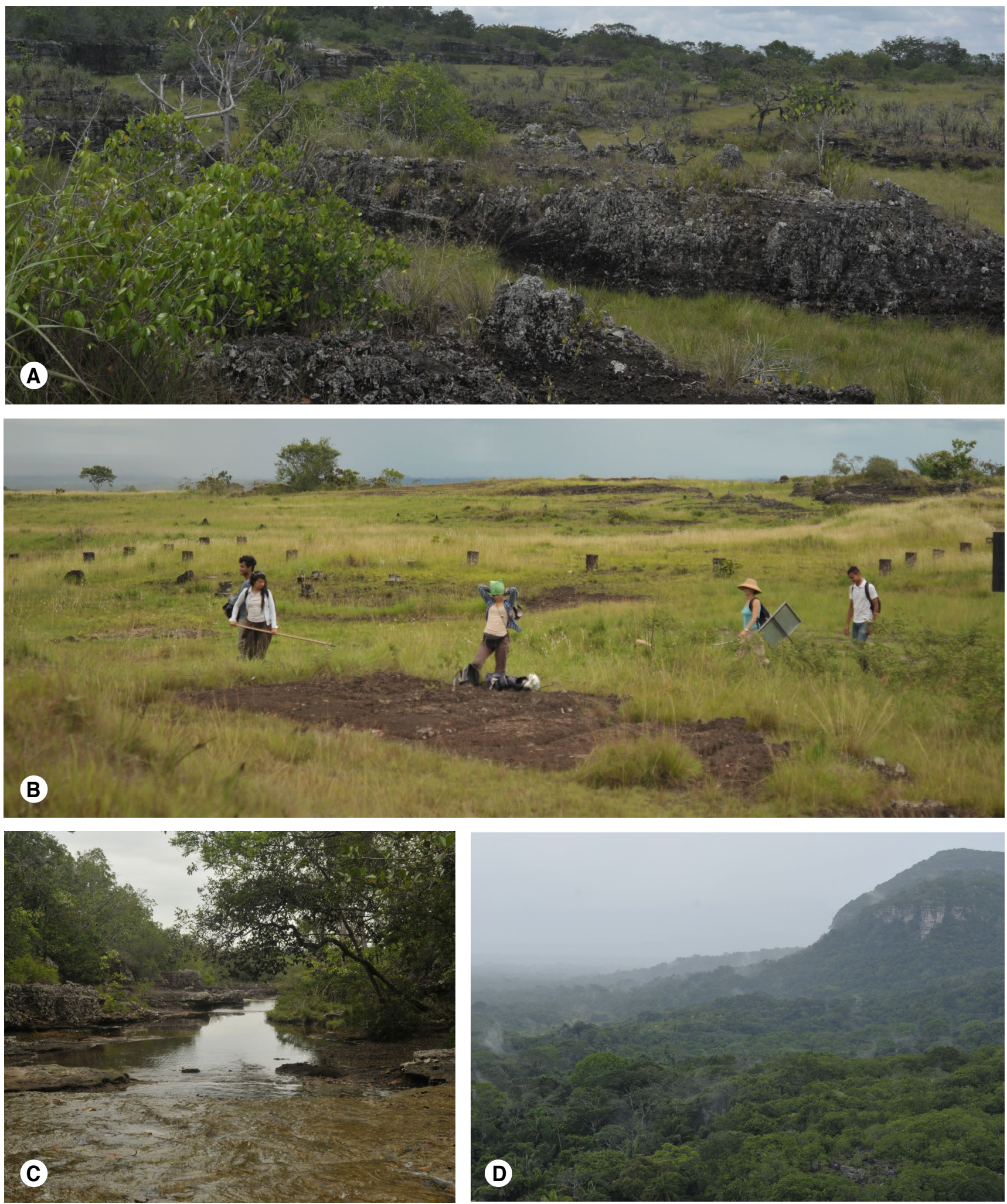

Figure 2. Types of vegetation present in San José del Guaviare, Guaviare, Colombia. A. Paleozoic rocky outcrops and forest. B. Grasslands - savanna. C. Wetlands - flooded forest. D. Native forests - tropical wet forest. Photos: Guido F. Medina-Rangel. 
A strong anthropic influence exists in this area, mainly due to habitat loss and deforestation of native forests caused by livestock, agriculture, and illicit coca crops associated with several social conflicts in the last decades (Armenteras \& Villa, 2006), despite the presence of the Nukak National Natural Reserve and Chiribiquete and La Macarena National Natural Parks. Also, this area has 14 indigenous reserves distributed in approximately 8 indigenous communities, among which the Nukak community is the largest and most influential in the region (Armenteras \& Villa, 2006).

Data collection. The amphibians and reptiles were sampled during four field trips, in October
2012, April and October 2013, and March 2014. Each field trip lasted 10 days. In total, we invested approximately 40 days of fieldwork, divided into 4 field campaigns with 6 people each. We employed an active searching strategy without replications in different habitats (Table 1), during diurnal samplings (9:00-13:00 h) each day, and nocturnal samplings (19:00-23:00 h) every other day. The specimens were collected in the leaf litter on the forest floor, on trunks and branches of trees, below flat stones and logs, or behind dead bracts of palm trees, and on the vertical surfaces of the rocky outcrops covered with tree roots that shelter animals, and on vegetation surrounding pools or streams.

Table 1. Sites of sampling in San Jose del Guaviare, Guaviare, Colombia.

\begin{tabular}{cccc}
\hline Site number & Sites of sampling & Latitude & Longitude \\
\hline 1 & Playa Güio & $2^{\circ} 34^{\prime} 24.70^{\prime \prime} \mathrm{N}$ & $72^{\circ} 42^{\prime} 48.99^{\prime \prime} \mathrm{W}$ \\
\hline 2 & La Pradera & $2^{\circ} 32^{\prime} 52.41^{\prime \prime} \mathrm{N}$ & $72^{\circ} 42^{\prime} 56.61^{\prime \prime} \mathrm{W}$ \\
\hline 3 & La Isla & $2^{\circ} 34^{\prime} 23.80^{\prime \prime} \mathrm{N}$ & $78^{\circ} 42^{\prime} 00.66^{\prime \prime} \mathrm{W}$ \\
\hline 4 & Puerta de Orión & $2^{\circ} 30^{\prime} 48.19^{\prime \prime} \mathrm{N}$ & $72^{\circ} 44^{\prime} 33.95^{\prime \prime} \mathrm{W}$ \\
\hline 5 & Ciudad de Piedra - Serranía La Lindosa & $2^{\circ} 27^{\prime} 55.64^{\prime \prime} \mathrm{N}$ & $72^{\circ} 42^{\prime} 10.96^{\prime \prime} \mathrm{W}$ \\
\hline 7 & Sabana La Fuga & $2^{\circ} 30^{\prime} 22.45^{\prime \prime} \mathrm{N}$ & $72^{\circ} 44^{\prime} 49.86^{\prime \prime} \mathrm{W}$ \\
\hline 8 & Puentes Naturales & $2^{\circ} 32^{\prime} 26.27^{\prime \prime} \mathrm{N}$ & $72^{\circ} 42^{\prime} 51.77^{\prime \prime} \mathrm{W}$ \\
\hline 9 & Cascada Las Delicias & $2^{\circ} 29^{\prime} 50.59^{\prime \prime} \mathrm{N}$ & $72^{\circ} 41^{\prime} 10.02^{\prime \prime} \mathrm{W}$ \\
\hline 10 & Tranquilandia & $2^{\circ} 29^{\prime} 35,17^{\prime \prime} \mathrm{N}$ & $72^{\circ} 38^{\prime} 20.44^{\prime \prime} \mathrm{W}$ \\
\hline 11 & Cerro Azul & $2^{\circ} 34^{\prime} 51.96^{\prime \prime} \mathrm{N}$ & $72^{\circ} 49^{\prime} 51.85^{\prime \prime} \mathrm{W}$ \\
\hline
\end{tabular}


Additionally, we used a tetrad formation of drift fences with pitfalls as an unique trap structure (Crosswhite et al., 1999), with a total of four groups of traps located in the unflooded area of the forest in the site Playa Güio (Table 1).

Each captured individual was identified in the field, and, when possible, the specimens were photographed and released. Other specimens were collected and euthanized in $2 \%$ Roxicaine (reptiles), or by immersion in solution of Chlorobutanol (amphibians) (Pisani, 1973) fixed in $10 \%$ formalin solution, and preserved in $70 \%$ ethanol. The collected specimens were deposited in the Reptile and Amphibian collections of the Instituto de Ciencias Naturales (ICN), Universidad Nacional de Colombia.

We followed Peters \& Donoso-Barros (1970), Peters \& Orejas-Miranda (1970), Pérez-Santos \& Moreno (1988), Roze (1996), Campbell \& Lamar (2004), Duellman (2005), Rueda-Almonacid et al. (2007) and Cole et al. (2013) for specimen identification. To determine species conservation status, we used IUCN Red List for Threatened Species (IUCN, 2018). For taxonomic status, nomenclature, and distribution data of the species we used Batrachia (AcostaGalvis, 2019), AmphibiaWeb (AmphibiaWeb, 2019), Amphibian Species of the World (Frost, 2019), and Reptile Database (Uetz et al., 2019).

Additionally, we did a bibliographic search for records of herpetofauna species from the municipality of San José del Guaviare (AcostaGalvis et al., 2018a; Mueses-Cisneros \& CaicedoPortilla, 2018) and collected information of reliable records from the following herpetological collections: Amphibian collection and reptile collection of the Instituto de Ciencias Naturales - Universidad Nacional de Colombia (ICN) (http://ciencias. bogota.unal.edu.co/icn/colecciones-en-linea/), Museo de Historia Natural - Pontificia Universidad Javeriana (MUJ_REPT) and Instituto Alexander von Humboldt (IAvH-R) (SIB, 2019: http:/ / colecciones. biodiversidad.co/search?phylum=Chordata).
Data analysis. We estimated the species richness of amphibians and reptiles in the study area through a rarefaction and extrapolation curve (Chao et al., 2014). In addition, we used sampling coverage curves to obtain the percentage of completeness achieved by our inventory (CM \%) and estimated the additional coverage that would be needed to reach the maximum number of species. This analysis estimates the proportion of the total number of individuals in a community belonging to a species sampled (Chao \& Jost, 2012). For this, we used the iNEXT R package (Hsieh et al., 2016) and used 500 bootstraps to create $95 \%$ confidence intervals.

\section{Results}

We found a total of 103 species, distributed in 40 species of amphibians and 63 species of reptiles (Appendix 1). For amphibians, we found 1 order (Anura), 9 families, 18 genera and 40 species. The families with the highest number of species were Hylidae, followed by the family Leptodactylidae (Figure 3a). For reptiles, we recorded 3 orders (Crocodylia, Squamata, and Testudinidae), 19 families, 48 genera and 63 species (Figure 3, Appendix 1). For lizards, Teiidae was the family with the highest number of species, followed by Dactyloidae and Gymnophthalmidae (Figure $3 b$ ); for snakes, the family with more species was Colubridae, followed by Boidae (Figure 3c), and for turtles, Chelidae was the family with more species (Figure 3d).

We found 1298 specimens (692 amphibians and 606 reptiles; Appendix 1; Figure 4 illustrates some of the recorded species). The most abundant amphibians were Pristimantis vilarsi (171) (Figure 4A), Rhinella beebei (97), Leptodactylus fuscus (67), Rhinella marina (55) and Leptodactylus petersii (39), whereas for reptiles the most abundant were Gonatodes riveroi (111) (Figure 4M), Plica aff. plica (78) (Figure 4O), Lepidoblepharis nukak (71) (Figure 4N), Anolis fuscoauratus (54) and Anolis aff. auratus (26). 
A

AMPHIBIA

(Order Anura)

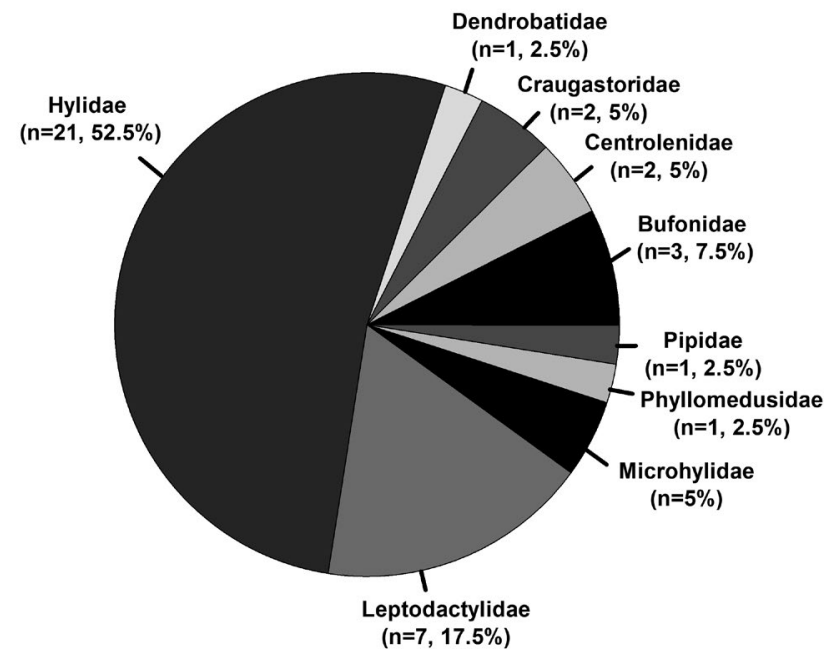

(C)

REPTILIA

(Suborder Serpentes)

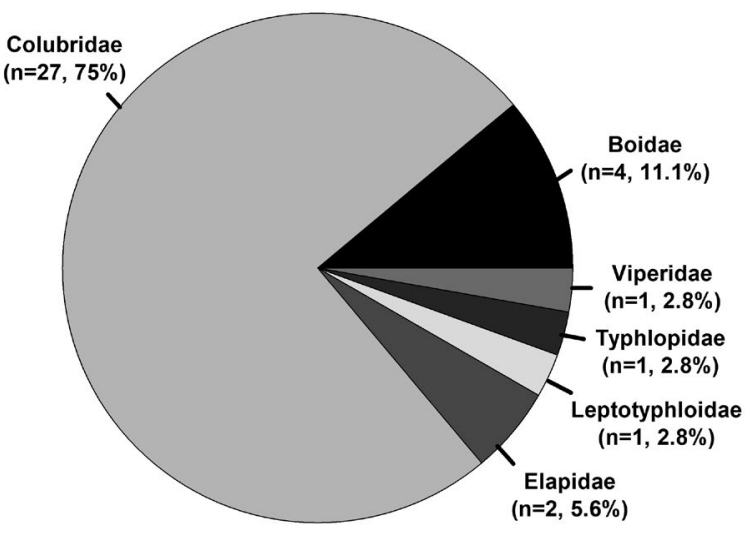

B

\section{REPTILIA}

(Suborder Sauria)

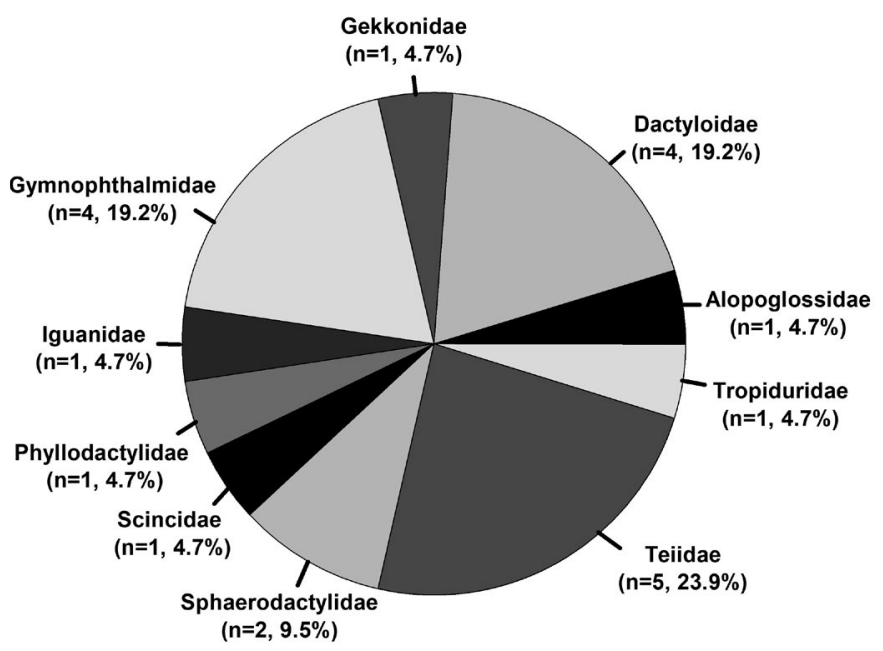

D

REPTILIA

(Orders Testudines \& Crocodylia)

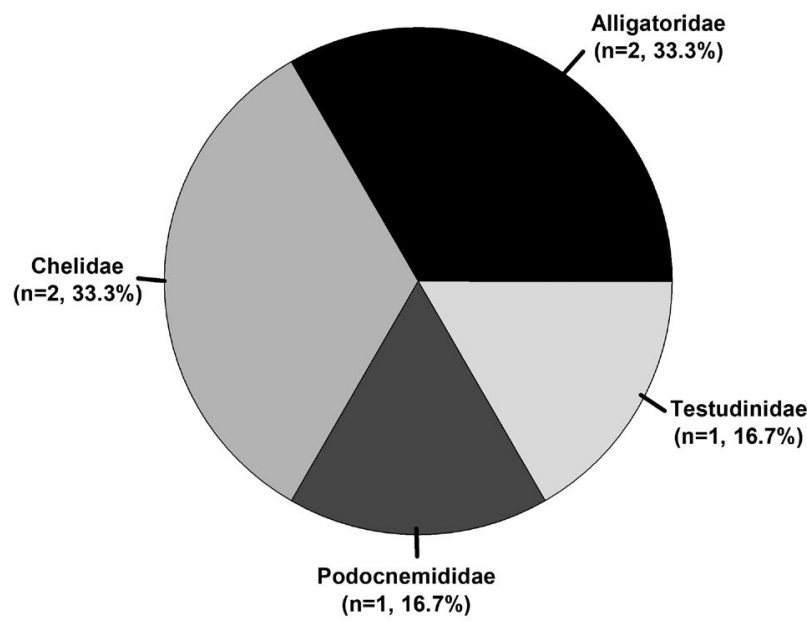

Figure 3. Diversity of amphibian (frogs) and reptile (lizards, snakes, crocodiles and turtles) families recorded in San José del Guaviare, Guaviare, Colombia. Values in parenthesis represent the total number of species, and the percentage of the familiy for each group. 

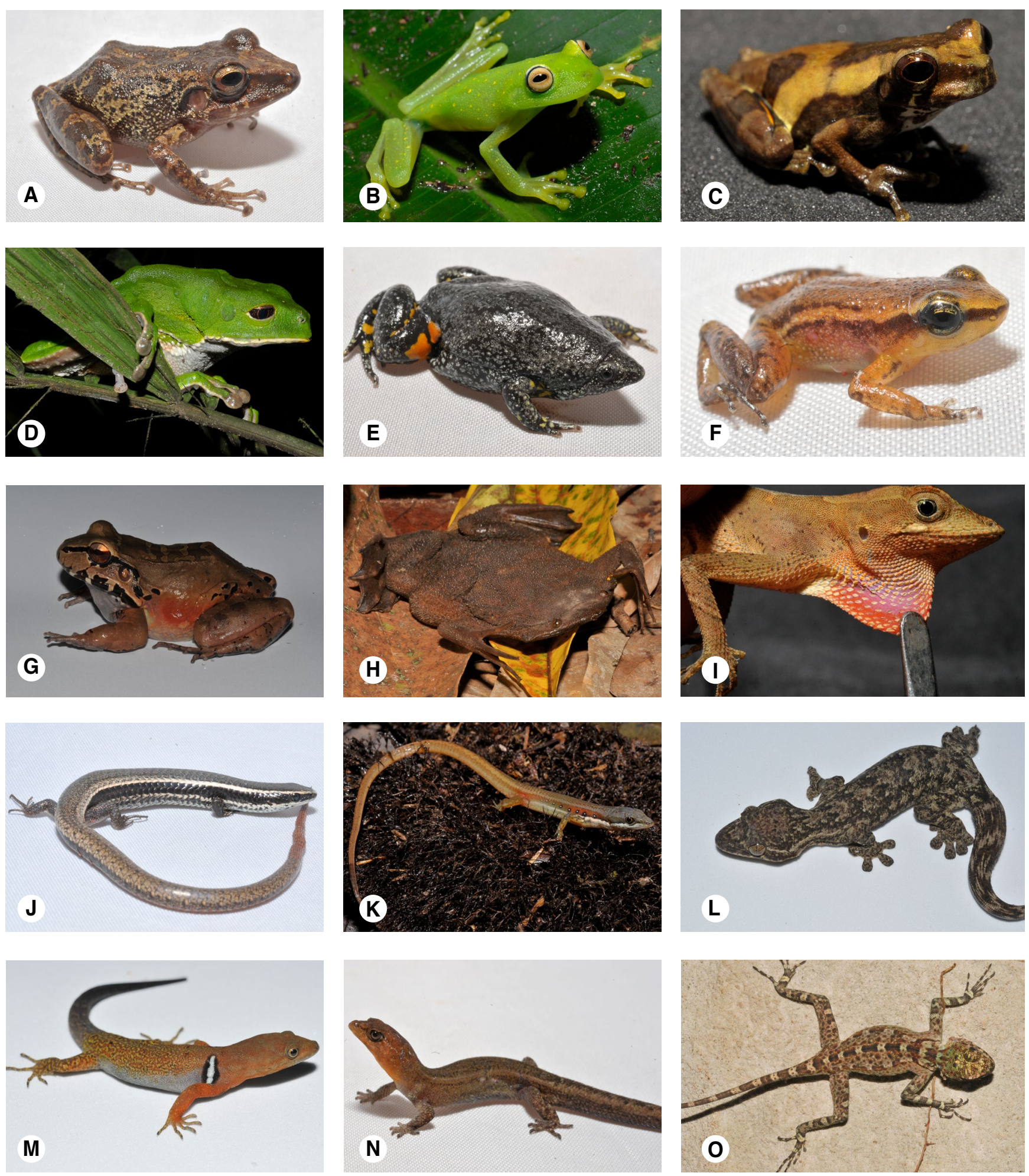

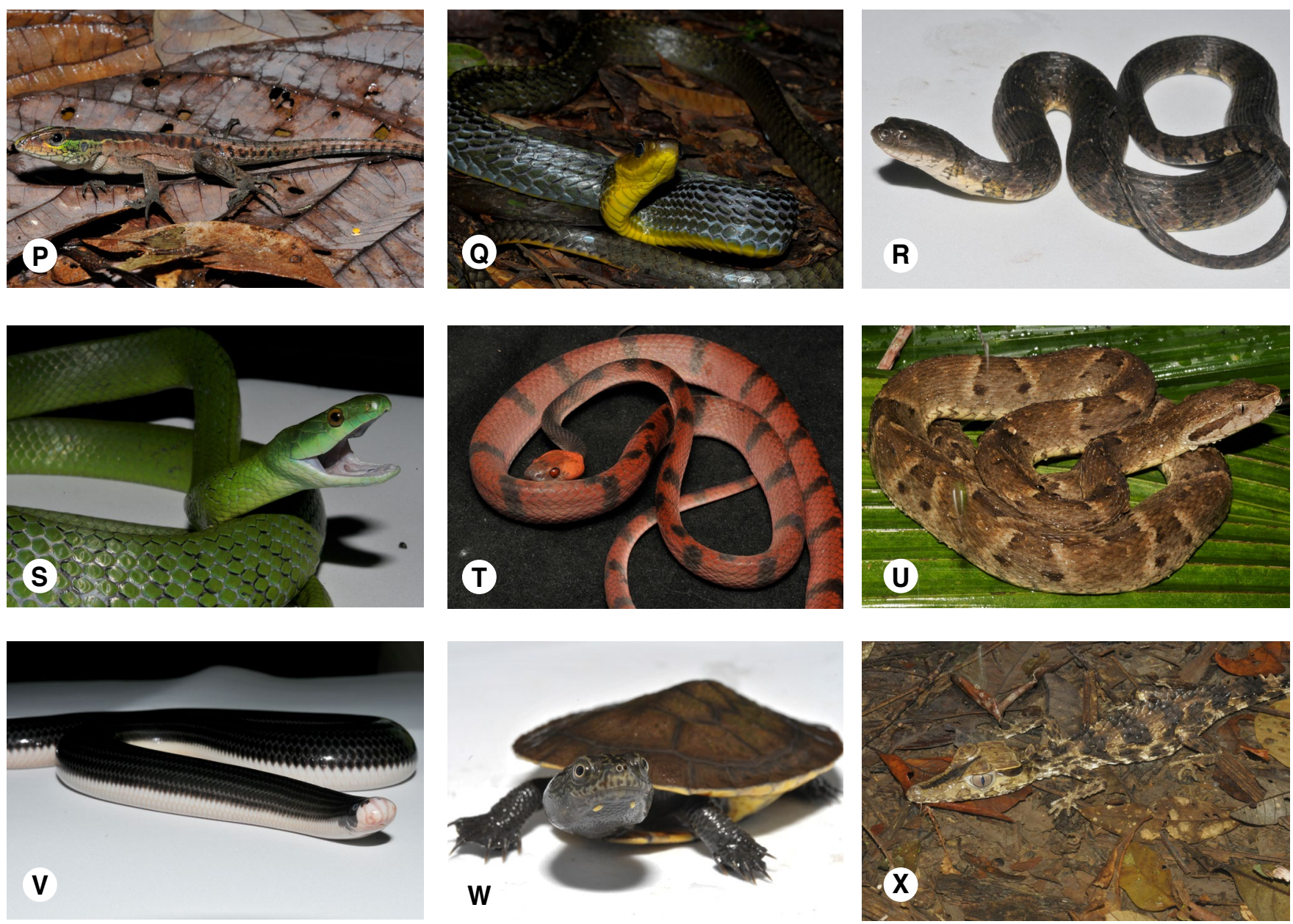

Figure 4. Some of the species of amphibians (frogs) and reptiles (lizards, snakes, crocodiles and turtles) recorded in San Jose del Guaviare, Guaviare, Colombia. Amphibians: A. Pristimantis vilarsi, B. Boana cinerascens, C. Dendropsophus parviceps, D. Phyllomedusa tarsius, E. Elachistocleis ovalis (nomen inquirendum), F. Hyloxalus picachos, G. Leptodactylus knudseni, H. Pipa pipa. Reptiles: I. Anolis scypheus, J. Gymnophthalmus leucomystax, K. Cercosaura argula, L. Thecadactylus rapicauda, M. Gonatodes riveroi, N. Lepidoblepharis nukak, O. Plica aff. plica, P. Kentropyx pelviceps, Q. Chironius scurrulus, R. Helicops angulatus, S. Philodryas viridissima, T. Siphlophis compressus, U. Bothrops atrox, V. Amerotyphlops reticulatus, W. Mesoclemmys gibba, X. Paleosuchus trigonatus. Photos: Guido F. Medina-Rangel. 
According to the coverage curves, we estimate that up to 165 species, around 49 amphibians and 120 reptiles, can be found with a greater sampling effort, when sampling coverage greater than $99 \%$ is reached (Figure $5 \mathrm{~A}$ ).

A

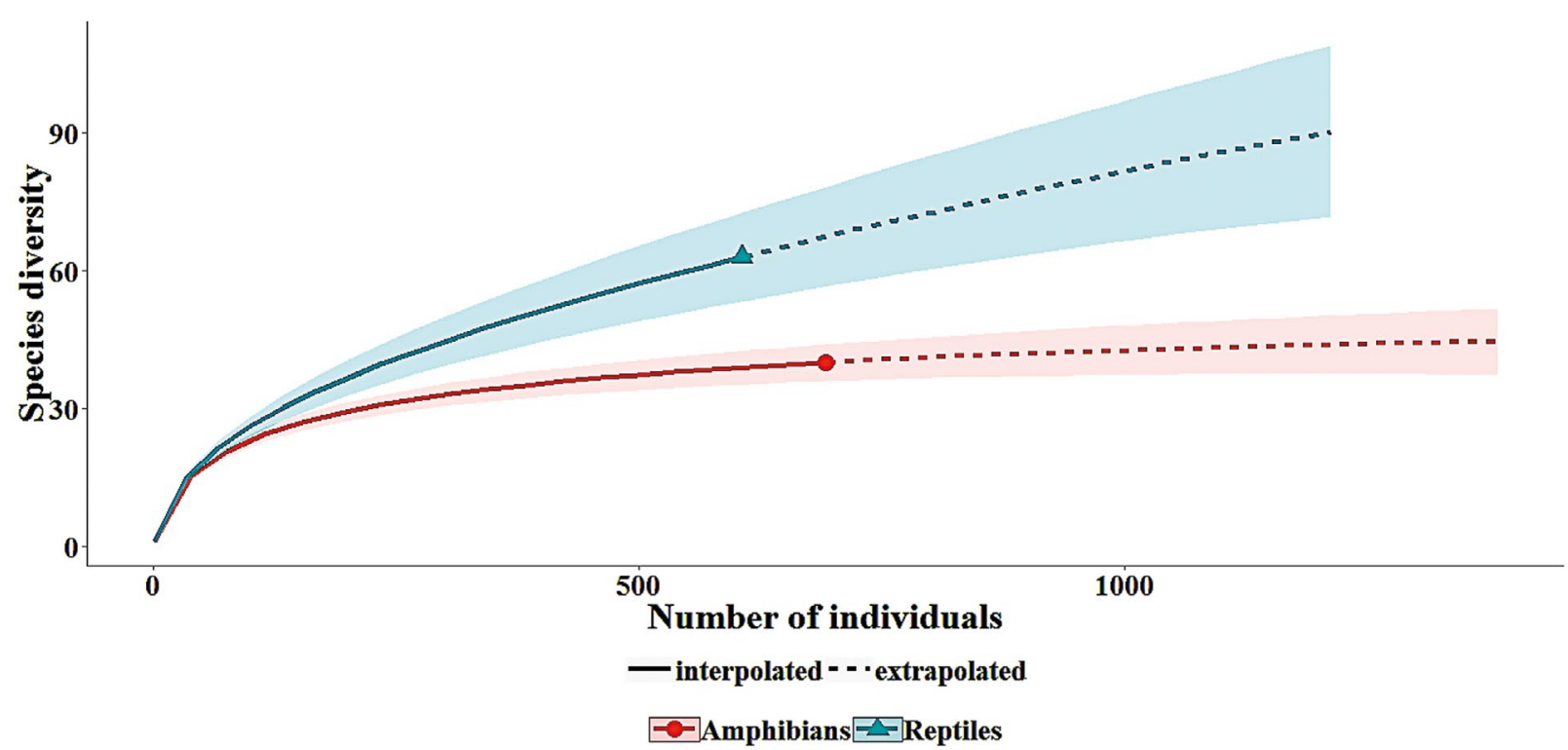

B

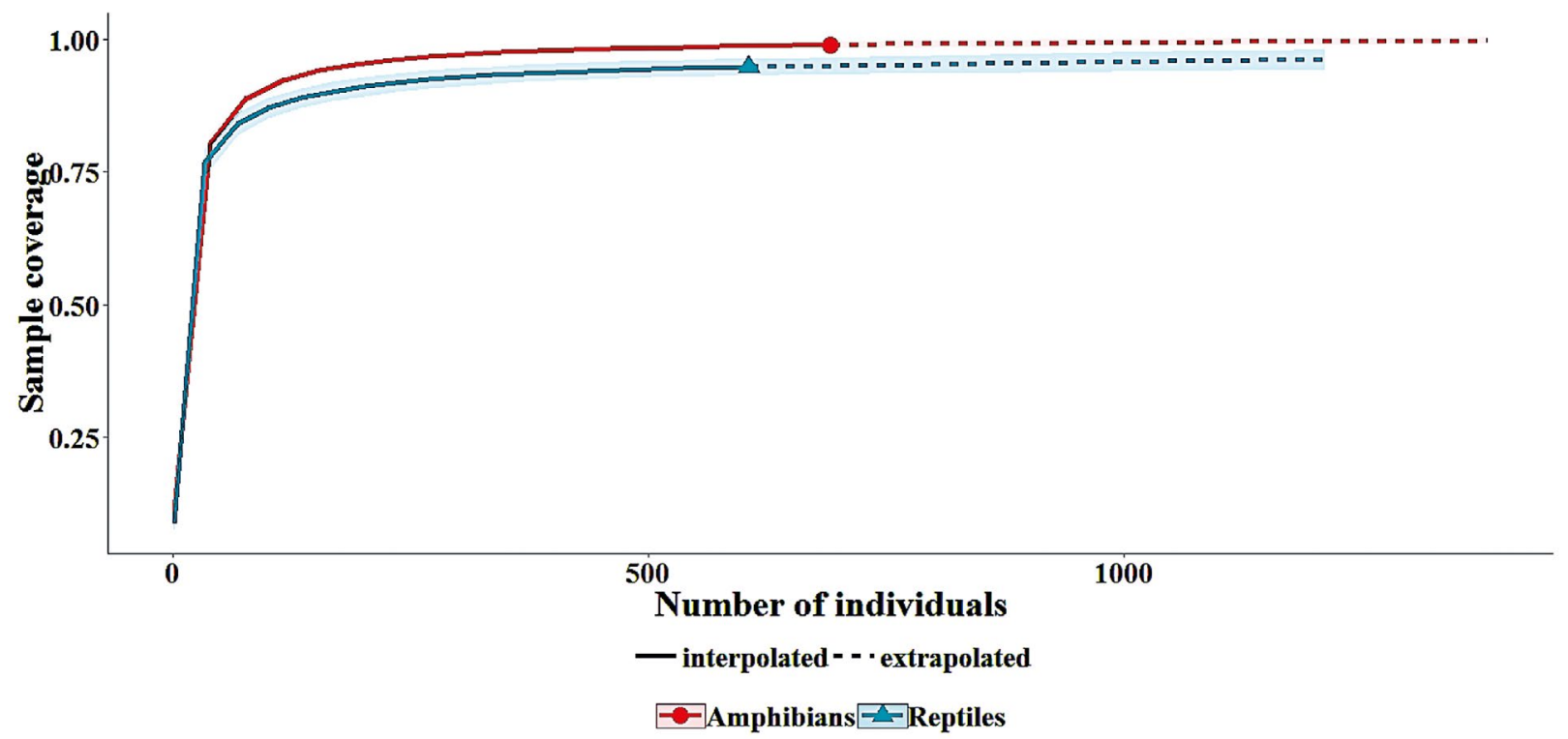

Figure 5. Richness and sample coverage curves of amphibians and reptiles recorded and estimated between 2012-2014 at San José del Guaviare, Guaviare, Colombia. A. Richness. B. Sampling coverage. Solid lines represent data collected during inventory. Dotted lines: represent estimates or extrapolations. Shaded areas represent the confidence interval of $95 \%$ generated by re-sampling (500 bootstraps). 
For the amphibians, we obtained a sampling coverage of $98 \%$, with 692 individuals, and for reptiles we had a sampling coverage of $94 \%$, with 606 individuals (Figure 5B). This inventory has shown slightly better results in recording amphibian richness than reptile richness.

Literature review and collection records increased by 7 the number of amphibian species and by 15 species of reptiles. Therefore, our species list for San José del Guaviare includes 47 taxa of amphibians, and 78 of reptiles (Appendix 1), with 45 species (20 amphibians and 25 reptiles, respectively) not previously recorded in collections or in Mueses-Cisneros \& Caicedo-Portilla (2018).

Most amphibian and reptile fauna found is widely distributed in the Amazon and/or Guiana Shield (38\%). More than $50 \%$ of the species were recorded in at least three or four ecoregions such as the Amazon, Orinoquia, Amazonian foothills, and Guiana Shield, while less than $12 \%$ occur in a single ecoregion or in specific localities (Appendix 1).

First record for Colombia. Gymnophthalmus leucomystax (Vanzolini \& Carvalho, 1991). (Figure 4J). ICN-R 12346, 12350, 12369. Lizard of the family Gymnophthalmidae with less than $41 \mathrm{~mm} \mathrm{SVL}$, with developed but short limbs with four fingers each; the snout in profile is rounded. The eye does not have movable eyelids. The dorsal background color is gray-brown with an iridescent effect. A dorsolateral cream-white stripe and a lateral wide dark brown stripe that begins at the snout only overlaps with the lower half of the ear opening and ends at the base of the tail; the tail is grayish brown and reddish orange at the tip. The venter is cream. This lizard has 13 midbody scales, a temporal scale separating the parietal from the occipital and visible from above, and two conspicuous scales in the posterior row of temporals contacting extensively with the occipital (García-Pérez \& Schargel, 2017; Recoder et al., 2018). The species was previously recorded for northeastern Brazil (Fazenda Salvamento, state of Roraima) and the southern part of Guyana (Aishalton on Kubanawau Creek, Southern Rupununi Savannah) (García-Pérez \& Schargel, 2017). This is the first record in Colombia, extending the species geographical distribution more than $1200 \mathrm{~km}$ west from its previously known nearest locality (Fazenda Salvamento, Roraima, Brazil).

Range extensions. Atractus collaris (Peracca, 1897). ICN-R 12818. Snake of the family Colubridae, characterized mainly by the contact between first supralabial and loreal, dorsal scale rows 17/17/17 with one or two apical pits and conspicuous spots, two postoculars, and yellow supralabials, and for having less than 186 ventral scales (Passos et al., 2018). It is distributed in Ecuador, Peru, and northern Brazil (Passos et al., 2018). In Colombia it occurs in different localities of the departments of Amazonas (La Pedrera), Caquetá (Florencia), Guainía (Caño Vitina Village, Inírida) and Vaúpes (Bellavista, Mitú, and Caparú Biological Station, Tararira) (Passos et al., 2018). Our records are the first for the department of Guaviare, extending its range to the north of the Colombian Amazon by more than $530 \mathrm{~km}$.

Atractus fuliginosus (Hallowell, 1845). ICN-R 12302. Snake of the family Colubridae, characterized by having 17/17/17 dorsal scale rows of light brown color and splashed with yellow and dark brown dots along the body. Flanks, upper lip and venter yellow. It is distributed in the eastern foothills of the Andes of Colombia and Venezuela (Natera-Mumaw et al., 2015; Rivas \& Schargel, 2017). This species occurs in Colombia in the departments of Arauca, Casanare and Meta (Villavicencio) (Pérez-Santos \& Moreno, 1988). These are the first records for the department of Guaviare, extending its range to the southeast by almost $170 \mathrm{~km}$ from the nearest locality (Villavicencio, Meta).

Boana maculateralis (Caminer \& Ron, 2014). ICN-A 56576-56582. Frog of the family Hylidae. Caminer \& Ron (2014) described four new species of the Boana calcarata and Boana fasciatus complex, including $B$. maculateralis. The frog has a pale creamy white to light brown dorsum with dispersed black dots, and a series of irregular black/bluish spots over a pale background on the groin, toward the lateral region of the body and hidden parts of the thighs. Heel with short tubercle. It is distributed in the Amazon basin of Ecuador and 
Peru (Caminer \& Ron, 2014). In Colombia it had been registered in the departments of Amazonas (Leticia), and Meta (Sierra de la Macarena National Park) (Acosta-Galvis et al., 2018 a, b). These are the first records for the department of Guaviare, extending its range to the northeast almost $150 \mathrm{~km}$ from the nearest locality (Sierra de la Macarena National Park, Meta).

Epictia amazonica (Orejas-Miranda, 1969). ICN-R 12459,12828 . Snake of the family Leptotyphlopidae, characterized mainly by uniform scales around the cylindrical body and short tail ending in conical tip. Dorsal scales arranged in rows of 14-14-14, and in rows of 10 at the middle of the tail. The background body color is brown, with four zigzagging golden lines, interleaved with pale brown lines. Head and tip of tail with a yellow spot. This species is very rare, with only six specimens in collections (Natera-Mumaw et al., 2015). It is distributed in Guyana, French Guiana and Venezuela (Orejas-Miranda, 1969; Uetz et al., 2019). Only two specimens had been collected in Colombia (MCZ-R 141087 - Carimagua, Meta, and IBSP 7204 -Unknown location; Pinto et al., 2010; Natera-Mumaw et al., 2015), but the specimen of the Instituto Butantan, Herpetological collection Alphonse Richard Hoge, São Paulo (IBSP), was destroyed by fire of May 15, 2010. For this reason, the two specimens collected in this study are particularly important. Our records are the first for the department of Guaviare, extending its range to the south almost $250 \mathrm{~km}$ from the nearest locality (Carimagua, Meta).

Potential taxonomic novelties. Scinax aff. blairi (ICN-A 56626) and Dendrophidion sp. (ICN-R 12301) are two potentially new species. Scinax aff. blairi is similar to a species of Scinax currently being described from Serranía de Chiribiquete National Natural Park (Lynch, J. D. pers. comm.), and Dendrophidion sp. turns out to be an undescribed species of the genus from Serranía de La Lindosa and other areas of the Colombian Amazonia (Caicedo-Portilla, J. R. Com. Pers.).

Vitreorana sp. 1 (ICN 56535), Vitreorana sp. 2 (ICN 56536), Anolis aff. auratus (ICN-R 12292, 12338, 12355, 12476, 12478), Plica aff. plica (ICN-R 12261-64, 12268, 12314-16, 12339, 12461-62; Figure 4O), and Helicops sp. (ICN-R 12519) are five species that require a more extensive review and more specimens are needed to clarify their taxonomic status.

\section{Discussion}

The herpetofauna recorded for the municipality of San José del Guaviare highlights the richness of the fauna of the northwestern Amazon in Colombia (north of Amazonas, west of Caquetá, Guainía, Guaviare, south of Meta, Vaupés and south of Vichada). In this work, we show a higher number of amphibians and reptiles for the Colombian Guiana Shield compared to other studies that have been conducted in the region (Lynch \& Vargas, 2000; Renjifo et al., 2009; Barrientos et al., 2017; Suárez-Mayorga \& Lynch, 2017; Acosta-Galvis, 2018; Acosta-Galvis et al., 2018b; Durán-Prieto et al., 2018). However, due to the extension of the region, further exploration is needed to know the true richness of amphibians and reptiles in this part of Colombia.

The fauna composition of amphibians and reptiles of San José del Guaviare is influenced by elements of Amazon, Guiana Shield, Orinoquia, and Andes systems, as has been suggested by other authors (Hammond, 2005; Huber, 2006; Suárez-Mayorga \& Lynch, 2017; Acosta-Galvis, 2018; Durán-Prieto et al., 2018). All of these elements converge on the different habitats provided mostly by the Guiana Shield formation. However, the sampled area is still small in comparison to the extension of the municipality.

The herpetofauna richness projections for this region (49 amphibians and 120 reptiles), suggests that this is a preliminary list of the amphibians and reptiles that inhabit the municipality of San José del Guaviare and nearby sites of the Serranía La Lindosa. MuesesCisneros \& Caicedo-Portilla (2018) estimate that 60 species of amphibians may occur in this area, a higher number than projected in this study.

We are aware that our sampling strategy was biased toward collecting specimens that perch on vegetation 
lower than $2 \mathrm{~m}$ high; therefore, species from the canopy might be absent of this inventory (for instance, some amphibian species of Osteocephalus spp., Hylidae and Phyllomedusidae and reptiles such as Anolis spp. and Tropiduridae). However, particular ecological conditions may facilitate recording of canopy species. For example, Medina-Rangel et al. (2019) found a large number of individuals and species of Osteocephalus by sampling in the beginning of the rainy season, at the precise moment when many of the canopy species descended for courtship, mating, and egg-laying.

Similarly, we did not actively search in streams and ponds, where up to four additional species of turtles could be found, such as Podocnemis expansa, in large rivers such as the Guaviare or the Guayabero (Ceballos et al., 2012), or Peltocephalus dumerilianus, Kinosternon scorpioides, and Platemys platycephala, that inhabit small bodies of water in the forest (De la Ossa et al., 2012a; Berry et al., 2012; De la Ossa et al., 2012b; MedinaRangel et al., 2019).

Moreover, the sampling effort of the locality of Cerro Azul was low, with just two days of fieldwork and only during the daytime. In spite of low sampling, we found 11 species (Appendix 1). This locality has a higher vegetation cover (tropical wet forest) than other localities included in this study, and therefore it should harbor many more species. Besides, Cerro Azul has an extensive forest continuously threatened by fires to expand the livestock frontier. The fires often get out of control, becoming a serious problem that affects other habitats, such as savannas or flooded forests (Armenteras-Pascual et al., 2011; Corredor-Llano et al., 2018).

Most of the amphibians and reptiles recorded in our study are from native forests and Paleozoic rocky outcrops, and a low proportion are exclusive of grasslands. The loss of large natural covers such as forests can have a great impact on the stability of the herpetofauna of San José del Guaviare. Deforestation, mainly as a consequence of cattle farming activities, is a stressor that unquestionably affects biodiversity in the Guaviare department. The high deforestation rate in the Amazonian region of Colombia makes increasing our knowledge of these ecosystems an urgent matter. Most importantly, local actors and environmental authorities should focus their efforts on planning conservation strategies for all biota in the region. Then, knowledge about biodiversity may strengthen the sense of belonging to the territory and thereby contribute to conservation and management of biodiversity in this region.

\section{Acknowledgements}

We would like to thank Área Curricular de Biología, Facultad de Ciencias, Universidad Nacional de Colombia, Bogotá, for the financial support of the fieldwork through the Animal Taxonomy course, which allowed us to record the species included in this study. We are also grateful to the Melo Vargas family and community of Playa Güio (especially Javier, Myriam, Marcos, Diana, Isabela, Leonor, Wilmer, José, Arnulfo, don Chucho and don Álvaro) for their help, affection, and hospitality during fieldwork. Thank you to the students of Animal Taxonomy during 2012-2014, for their support in the collection of specimens, especially to Miller Castañeda. We thank Walter Schargel for confirming the identity of Gymnophthalmus leucomystax. We appreciate the comments and suggestions of the two anonymous reviewers. We collected the specimens under a permit issued by the Corporación para el Desarrollo Sostenible del Norte y el Oriente Amazónico-CDA, with resolution number DSGV-112 of the 25th October of 2012.

\section{References}

Acosta-Galvis, A. R. (2018). Anfibios del Escudo Guayanés de Colombia: una aproximación preliminar. En Lasso, C. A. \& Señaris, J. C. (Eds.), Volumen VI. Fauna Silvestre del Escudo Guayanés (Colombia-Venezuela). Pp: 61-100. Serie Editorial Fauna Silvestre Neotropical. Bogotá, D. C., Colombia: Instituto de Investigación de Recursos Biológicos Alexander von Humboldt. 438 pp. 
Acosta-Galvis, A. R., Lasso, C. A. \& Morales-Betancourt, M. A. (2018a). First record of Boana maculateralis (Caminer \& Ron, 2014) and Boana tetete (Caminer \& Ron, 2014) (Anura, Hylidae) in Colombia. Check List, 14(3), 549-554. https://doi. org/10.15560/14.3.549

Acosta-Galvis, A. R., Morales-Betancourt, M. A., Lasso, C. A., Rayo, D., Lomelin, J. C. \& Lomelin, A. (2018b). Anfibios y reptiles de los ríos Guayabero medio, bajo Losada y bajo Duda, sierra de La Macarena, Meta, Colombia. En Lasso, C. A., Morales-Betancourt, M. A. \& Escobar-Martínez, I. D. (Eds.). V. Biodiversidad de la sierra de La Macarena, Meta, Colombia. Parte I. Ríos Guayabero medio, bajo Losada y bajo Duda. Bogotá, D. C., Colombia: Serie Editorial Fauna Silvestre Neotropical. Instituto de Investigación de Recursos Biológicos Alexander von Humboldt. 329 pp.

Acosta-Galvis, A. R. (2019). Lista de los Anfibios de Colombia: Referencia en línea V.09.2019, accessed [31 January 2019]. Página web accesible en http:// www.batrachia.com; Batrachia, Villa de Leyva, Boyacá, Colombia.

AmphibiaWeb. (2019). <https://amphibiaweb.org> University of California, Berkeley, CA, USA, accessed 31 January 2019.

Armenteras, P. \& Villa, C. M. (2006). Deforestación y fragmentación de ecosistemas naturales en el Escudo Guayanés colombiano. Bogotá, D.C., Colombia: Instituto de Investigación de Recursos Biológicos Alexander von Humboldt e Instituto Colombiano para el Desarrollo de la Ciencia y la Tecnología "Francisco José de Caldas" -Colciencias-.124 pp.

Armenteras-Pascual, D., Retana-Alumbreros, J., Molowny-Horas, R., Román-Cuesta, R. M., González-Alonso, F. \& Morales-Rivas, M. (2011). Characterising fire spatial pattern interactions with climate and vegetation in Colombia. Agricultural and Forest Meteorology, 151, 279-289.

Barrientos, L. S., Morales-Betancourt, M. A., Lasso, C. A., Torres, G. \& Herrera, P. (2017). Anfibios y Reptiles. En Lasso, C. A. \& Morales-Betancourt, M. A. (Eds.). III. Fauna de Caño Cristales, Sierra La Macarena, Meta, Colombia. Serie Editorial Fauna Silvestre Neotropical. Pp: 97-123. Bogotá, D. C., Colombia: Instituto de Investigación de Recursos Biológicos Alexander von Humboldt. 189 pp.

Berry, J. F., Iverson, J. B. \& Forero-Medina, G. (2012). Kinosternon scorpioides. En Páez, V. P., Morales-Betancourt, M. A., Lasso, C. A., Castaño-Mora, O. V. \& Bock, B. C. (Eds.). Biología y conservación de las tortugas continentales de Colombia. Pp: 340-348. Bogotá, D.C., Colombia: Serie Editorial Recursos Hidrobiológicos y Pesqueros Continentales de Colombia. Instituto de Investigación de Recursos Biológicos Alexander von Humboldt. 528 pp.

Caminer, M. A. \& Ron, S. R. (2014). Systematics of treefrogs of the Hypsiboas calcaratus and Hypsiboas fasciatus species complex (Anura, Hylidae) with the description of four new species. ZooKeys, 370, 1-68.

Campbell, J. \& Lamar, W. (2004). The venomous reptiles of the western hemisphere. Vol. I-II. Ithaca and London: Comstock Publishing Associates and Division of Cornell University Press. 870 pp.

Cárdenas-López, D., Castaño-Arboleda, N., Zubieta-Vega M. \& Jaramillo-Echeverry, M. (2008). Flora de las formaciones rocosas de la serranía de La Lindosa. Bogotá D. C.: Instituto Amazónico de Investigaciones Científicas "Sinchi". 162 pp.

Ceballos, C. P., Hernández, O., Morales-Betancourt, M. A. \& Trujillo, F. (2012). Podocnemis expansa. En Páez, V. P., Morales-Betancourt, M. A., Lasso, C. A., Castaño-Mora, O. V. \& Bock, B. C. (Eds.). Biología y conservación de las tortugas continentales de Colombia. Pp: 367-374. Bogotá, D.C., Colombia: Serie Editorial Recursos Hidrobiológicos y Pesqueros Continentales de Colombia. Instituto de Investigación de Recursos Biológicos Alexander von Humboldt. 528 pp.

Chao, A. \& Jost, L. (2012). Coverage-based rarefaction and extrapolation: standardizing samples by completeness rather than size. Ecology, 93, 2533-2547.

Chao, A., Gotelli, N. J., Hsieh, T. C., Sander, E. L., Ma, K. H., Colwell, R. K. \& Ellison, A. M. (2014). Rarefaction and extrapolation with Hill numbers: a framework for sampling and estimation in species diversity studies. Ecological Monographs, 84, 45-67.

Cole, C. J., Townsend, C. R., Reynolds, R. P., Mac Culloch, R. D. \& Lathrop, A. (2013). Amphibians and reptiles of Guyana, South America: Illustrated keys, annotated species accounts, and a biogeographic sy- 
nopsis. Proceedings of the Biological Society of Washington, 125(4), 317-578.

Corredor-Llano, X., Armenteras-Pascual, D. \& Niño, L. F. (2018). ¿Cuán grande es un incendio en las sabanas del norte de Suramérica? Perspectivas Rurales Nueva Época, 16(31), 25-40.

Crosswhite, D. L., Fox, S. F. \& Thill, R. L. (1999). Comparison of Methods for Monitoring Reptiles and Amphibians in Upland Forests of the Ouachita Mountains. Proceedings of the Oklahoma Academy of Science, 79, 45-50.

De la Ossa, J., Vogt, R. C., De la Ossa-Lacayo, A. \& Lasso, C. A. (2012a). Peltocephalus dumerilianus. En Páez, V. P., Morales-Betancourt, M. A., Lasso, C. A., Castaño-Mora, O. V. \& Bock, B. C. (Eds.). Biología y conservación de las tortugas continentales de Colombia. Pp: 353-359. Bogotá, D.C., Colombia: Serie Editorial Recursos Hidrobiológicos y Pesqueros Continentales de Colombia. Instituto de Investigación de Recursos Biológicos Alexander von Humboldt. 528 pp.

De la Ossa, J., Bernhard, R. \& De la Ossa-Lacayo, A. (2012b). Platemys platycephala. En Páez, V. P., Morales-Betancourt, M. A., Lasso, C. A., Castaño-Mora, O. V. \& Bock, B. C. (Eds.). Biología y conservación de las tortugas continentales de Colombia. Pp: 261-265. Bogotá, D.C., Colombia: Serie Editorial Recursos Hidrobiológicos y Pesqueros Continentales de Colombia. Instituto de Investigación de Recursos Biológicos Alexander von Humboldt. 528 pp.

Durán-Prieto, C., Lasso, C. A., Morales-Betancourt, M. A. \& Rojas-Runjaic, F. J. M. (2018). Reptiles del Escudo Guayanés en Colombia. En Lasso, C. A. \& Señaris, J. C. (Eds.), Volumen VI. Fauna Silvestre del Escudo Guayanés (Colombia-Venezuela). Pp: 151-177. Bogotá, D. C., Colombia: Serie Editorial Fauna Silvestre Neotropical. Instituto de Investigación de Recursos Biológicos Alexander von Humboldt. 438 pp.

Duellman, W. (2005). Cusco Amazónico: The Lives of Amphibians and Reptiles in an Amazonian Rainforest. Ithaca and London: Cornell University Press. 488 pp.

Frost, D. (2019). Amphibian Species of the World: An Online Reference, version 6.0, accessed [31 January 2019], database accessible at http:/ / research.amnh. org/herpetology/amphibia/index.html, American Museum of Natural History, New York, USA.
García-Pérez, J. E. \& Schargel, W. E. (2017). A new species of Gymnophthalmus (Squamata: Gymnophthalmidae) from sand dunes of the Llanos of Apure, Venezuela. Zootaxa, 4318(3), 576-586.

Hammond, D. (2005). Tropical forests of the Guiana Shield: Ancient forests of the modern world. Cambridge: CABI Publishing. 535 pp.

Hsieh, T. C., Ma, K. H. \& Chao, A. (2016). iNEXT: An R package for interpolation and extrapolation of species diversity (Hill numbers). Methods in Ecology and Evolution, 7(12), 1451-1456.

Huber, O. (2006). Herbaceous ecosystems on the Guiana Shield, a regional overview. Journal of Biogeography, 33, 464-475.

IUCN. (2018) The IUCN Red List of Threatened Species. Version 2018-2. http://www.iucnredlist.org. Downloaded on 31 January 2019.

Köhler, G. \& Kieckbusch, M. (2014). Two new species of Atractus from Colombia (Reptilia, Squamata, Dipsadidae). Zootaxa, 3872(3), 291-300.

Kok, P. J. R., Mac Culloch, R. D., Gaucher, P., Poelman, E. H., Bourne, G. R., Lathrop, A. \& Lenglet, G. L. (2006). A new species of Colostethus (Anura, Dendrobatidae) from French Guiana with a redescription of Colostethus beebei (Noble, 1923) from its type locality. Phyllomedusa, 5, 43-66.

Lynch, J. D. \& Vargas Ramírez, M. A. (2000). Lista preliminar de especies de anuros del departamento del Guainía. Revista de la Academia Colombiana de Ciencias Exactas Físicas y Naturales, 24(93), 579-589.

Medina-Rangel, G. F., Thompson, M. E. \& Ruiz, D. H. (2019). Anfibios y reptiles. En Reyes, D. A., Botero-García, R., del Campo, Á., Kotlinski, N., Lemos, A., Miller, T., Pitman, N., de Souza, L., Stotz, D. F., Salazar-Molano, A., Samper-Samper, F., Thompson, M. E., Vásquez-Cerón, A., Vriesendorp, C. \& Wachter, T. (Eds). Colombia: Bajo Caguán-Caquetá. Pp: 107116. Chicago: The Field Museum, Rapid Biological and Social Inventories Report 30. 447 pp.

Mueses-Cisneros, J. J. \& Caicedo-Portilla, J. R. (2018). Anfibios y reptiles. En Vriesendorp, C., Pitman, N., Alvira-Reyes, D., Salazar Molano, A., Botero-García, R., Arciniegas, A., de Souza, L., del Campo, Á., Stotz, D. F., Wachter, T., Ravikumar A. \& Peplinski, J. (Eds.), Colombia: La Lindosa, Capricho, Cerritos. Pp: 
117-126. Chigago: The Field Museum, Rapid Biological and Social Inventories Report 29. 268 pp.

Natera-Mumaw, M., Esqueda-González, L. F. \& Castelaín-Fernández, M. (2015). Atlas Serpientes de Venezuela. Una visión actual de su diversidad. Caracas, Venezuela: Dimacofi Negocios Avanzados S.A. 456 pp.

Orejas-Miranda, B. (1969). Tres nuevos Leptotyphlops (Reptilia: Serpentes). Comunicaciones Zoologicas del Museo de Historia Natural de Montevideo, 10(124), 1-11.

Passos, P., Prudente, A. L. C., Ramos, L. O., Caicedo-Portilla, J. R. \& Lynch, J. D. (2018). Species delimitations in the Atractus collaris complex (Serpentes: Dipsadidae). Zootaxa, 4392(3), 491-520.

Pérez-Santos, C. \& Moreno, A. G. (1988). Monografía VI. Ofidios de Colombia. Torino. 512 pp.

Peters, J. A. \& Orejas-Miranda, B. (1970). Catalogue of the Neotropical Squamata Part I. Snakes. Washington: Smithsonian Institution Press. 347 pp.

Peters, J. A. \& Donoso-Barros, R. (1970). Catalogue of the Neotropical Squamata Part II. Lizards and Amphisbaenians. Washington: Smithsonian Institution Press. 293 pp.

Pinto, R. R., Passos, P., Caicedo-Portilla, J. R., Arredondo, J. C. \& Fernandes, R. (2010). Taxonomy of the Threadsnakes of the tribe Epictini (Squamata: Serpentes: Leptotyphlopidae) in Colombia. Zootaxa, 2724, 1-28.

Pisani, G. R. (1973). A guide to preservation techniques for amphibians and reptiles. Society for the Study of Amphibians and Reptiles. Herpetological Circular, $1,1-22$.

Prance, G. T. (1996). Islands in Amazonas. Philosophical Transactions: Biological Sciences, 351 (1341), 823-833.

Rangel-Ch., J. O., Lowy-C., P. \& Aguilar-P., M. (1997). Colombia Diversidad Biótica II. Bogotá D.C: Instituto de Ciencias Naturales, Universidad Nacional de Colombia \& IDEAM. 436 pp.

Recoder, R. S., Dal Vechio, F., Marques-Souza, S., Teixeira Jr., M., Silva-Da-Silva, M., Santos-Jr., A. P., Ribeiro,
S., Barrio-Amorós, C. \& Rodrigues, M. T. (2018). Geographic variation and taxonomy of red-tailed Gymnophthalmus (Squamata: Gymnophthalmidae) from Amazonian Savannas. Zootaxa, 4497(1), 061-081.

Rivas, G. \& Schargel, W. (2017). Atractus fuliginosus. The IUCN Red List of Threatened Species 2017: e. T67610419A67610434. http://dx.doi.org/10.2305/ IUCN.UK.2017-2.RLTS.T67610419A67610434.en. Downloaded on 04 February 2019.

Renjifo, J. M, Lasso, C. A. \& Morales-Betancourt, M. A. (2009). Herpetofauna de la Estrella Fluvial de Inírida (ríos Inírida, Guaviare, Atabapo y Orinoco), Orinoquia colombiana: Lista preliminar de especies. Biota Colombiana, 10(1-2), 171-178.

Roze, J. A. (1996). Coral Snakes of the Americas - Biology, identification, and venoms. Malabar, Florida: Krieger Publishing Company. 328 pp.

Rueda-Almonacid, J. V., Lynch, J. D. \& Amezquita, A. (2004). Libro Rojo de Anfibios de Colombia. Bogotá D. C., Colombia: Conservación Internacional Colombia, Instituto de Ciencias Naturales - Universidad nacional de Colombia, Ministerio del Medio Ambiente. 384 pp.

Rueda-Almonacid, J. V., Carr, J. L., Mittermeier, R. A., Rodríguez-M., J. V., Mast, R. B., Vogt, R. C., Rhodin, A. G. J., de La Ossa-V., J., Rueda, J. N. \& Mittermeier, C. G. (2007). Las tortugas y los cocodrilianos de los países andinos del trópico. Bogotá D. C: Serie de guías tropicales de campo $\mathrm{N}^{\circ} 6$. Conservación Internacional. $538 \mathrm{pp}$.

Suárez-Mayorga, A. M. \& Lynch, J. D. (2017). Myth and truth on the herpetofauna of Chiribiquete: from the lost world to the last world. Revista Colombia Amazónica, 10, 177-190.

Uetz, P., Freed, P. \& Hošek, J. (Eds.) (2019). The Reptile Database, http:/ / www.reptile-database.org, accessed [31 January 2019]. 
Appendix 1. Amphibians (frogs) and reptiles (lizards, snakes, crocodiles and turtles) recorded from San José del Guaviare, Guaviare, Colombia.

Appendix 2. Collection codes from the collected amphibians (frogs) and reptiles (lizards and snakes) recorded from San José del Guaviar e, Guaviare, Colombia.

Available online: http://revistas.humboldt.org.co/index.php/biota/rt/suppFiles/675/0.

\section{Guido Fabian Medina-Rangel}

Universidad Nacional de Colombia,

Instituto de Ciencias Naturales

Bogotá, Colombia

gfmedinar@unal.edu.co

https://orcid.org/0000-0002-9609-590X

\section{Miguel Á. Méndez-Galeano}

Universidad Nacional de Colombia, Instituto de Ciencias Naturales

Bogotá, Colombia

miamendezga@unal.edu.co

https://orcid.org/0000-0002-2391-1144

\section{Martha Lucía Calderón-Espinosa}

Universidad Nacional de Colombia,

Instituto de Ciencias Naturales

Bogotá, Colombia

mlcalderone@unal.edu.co

https://orcid.org/0000-0002-3602-013X

\section{Herpetofauna of San José del Guaviare, Guaviare, Colombia}

Citación del artículo: Medina-Rangel, G. F., Méndez-Galeano, M. A. \& Calderón-Espinosa, M. L. (2019). Herpetofauna of San José del Guaviare, Guaviare, Colombia. Biota Colombiana, 20(1), 75-90. DOI: 10.21068/ c2019.v20n01a05.

Recibido: 2 de marzo de 2019

Aceptado: 13 de mayo de 2019 